\title{
Modeling of storage tank settlement based on the United States standards
}

\author{
Alesya Gruchenkova ${ }^{1, *}$, Aleksandr Tarasenko ${ }^{2}$, and Petr Chepur ${ }^{2}$ \\ ${ }^{1}$ Surgut Institute of Oil and Gas, Surgut Branch of the Tyumen Industrial University, 628404 Surgut, \\ Russia \\ ${ }^{2}$ Tyumen Industrial University, 625000 Tyumen, Russia
}

\begin{abstract}
Up to $60 \%$ of storage tanks in operation have uneven settlement of the outer bottom contour, which often leads to accidents. Russian and foreign regulatory documents have different requirements for strain limits of metal structures. There is an increasing need for harmonizing regulatory documents. The aim of this study is to theoretically justify and to assess the possibility of applying the U.S. standards for specifying the allowable settlement of storage tanks used in Russia. The allowable uneven settlement was calculated for a vertical steel tank (VST-20000) according to API-653, a standard of the American Petroleum Institute. The calculated allowable settlement levels were compared with those established by Russian standards. Based on the finite element method, the uneven settlement development process of a storage tank was modeled. Stressstrain state parameters of tank structures were obtained at the critical levels established in API-653. Relationships of maximum equivalent stresses in VST metal structures to the vertical settlement component for settlement zones of 6 to $72 \mathrm{~m}$ in length were determined. When the uneven settlement zone is $6 \mathrm{~m}$ in length, the limit state is found to be caused by $30-\mathrm{mm}$ vertical settlement, while stresses in the wall exceed $330 \mathrm{MPa}$. When the uneven settlement zone is $36 \mathrm{~m}$ in length, stresses reach the yield point only at $100-\mathrm{mm}$ vertical settlement.
\end{abstract}

\section{Introduction}

Uneven settlement is one of the causes that give rise to limit states in metal structures of vertical steel tanks (VST), which often lead to accidents [1-3]. Effects of uneven foundation settlement on the stress-strain state of storage tanks were studied by Russian scientists, such as V. B. Galeev, V. V. Lyubushkin, V. A. Burenin, P. P. Borodavkin and others, as well as by foreign scientists - J. S. Clarke [4], E. E. DeBeer [5], D. A. Greenwood [6] and others. However, despite accumulated research findings and long-term experience in tank construction, researcher have failed to resolve a number of issues related to assessing the stress-strain state of VST, which is subject to uneven foundation settlement [7]. For non-axisymmetric strains of a tank shell, it is not always possible to determine high-stress zones in metal structures [8].

*Corresponding author: alesya2010-11@yandex.ru 
To prevent unacceptable stresses in the VST structure, Russian and foreign regulatory documents specify the criteria that determine allowable uneven settlement levels. For example, regulatory documents of the Russian Federation (GOST, RD, SA, RB) and the USA (API) contain the specific formulas, relationships and tabular values, which allow the maximum settlement level to be determined for VST of various designs and sizes.

Internationalization, globalization of energy markets, and, therefore, the involvement of foreign contractors for constructing storage tanks in the Russian Federation make it necessary to harmonize the Russian regulatory framework in the field of storage tank construction. An important problem is that the storage tanks constructed according to Russian and western standards have some differences in terms of design and materials [11]. In turn, this affects the overall stiffness of the structure, which determines the deformation behavior of the VST shell in case of uneven settlement. Thus, the authors aim to theoretically justify and to assess the possibility of applying the U.S. standards for determining the stress-strain state of storage tanks of Russian standard sizes.

\section{Materials and Methods}

The authors suggest considering the possibility of using the requirements of API-653 standard (Appendix B) [12] for specifying allowable settlement levels in Russian storage tanks. In order to justify the possibility of using the American API standard, it is necessary to perform a number of verifications of the stress-strain state for VST structure at given uneven settlement parameters, to determine effective stresses in structural elements, and to compare them with allowable values for a certain steel grade (09G2S). The authors will consider the most common storage tank of the Russian Federation - VST-20000 with a fixed roof and reinforced concrete foundation ring.

To perform the tasks set in the paper, the authors applied the classical principles of structural mechanics, the theory of elasticity, deformable body mechanics, and the finite element method. Being a numerical method, the finite element method can be used to solve a wide range of physical problems, which are mathematically formulated through systems of differential equations. This method is suitable for a deep analysis of the stress-strain state in metal structures. Theoretical studies were carried out using methods of mathematical analysis and numerical modeling with the ANSYS software certified by the Federal Nuclear and Radiation Safety Authority of Russia.

The reliability of the obtained results is confirmed by satisfactory correlation with widely known analytical solutions. Moreover, it is supported by the research methodology proposed by Russian and foreign scientists, using regulatory documents and statistical data, minimal errors of calculated and experimental data, and the compliance of the data with scientific concepts.

The methods described above made it possible to obtain new relationships of the VST stress-strain state to dimensions of the uneven settlement zone. These relationships reflect the real deformation behavior of metal structures, taking into account the physical and geometric nonlinearity of the applicable model.

\section{Experimental Part}

According to API-653 [12], the maximum allowable settlement level is calculated on an individual case basis for each storage tank with uneven settlement components. For this purpose, it is necessary to level the outer bottom contour and to plot a distortion curve. Then uneven settlement zones are identified, and their length $\mathrm{S}_{\text {arc }}$, the so called "settlement arc", is determined. The maximum allowable vertical component, $\mathrm{S}_{\max }$, is calculated for 
each settlement arc according to the formula (1). This formula (API-653, Appendix B.3.2.2) takes VST diameter, height, and steel grade into account. Table 1 presents additional dimensionless coefficients and type of VST design selected according to the tank diameter.

$$
S_{\max }=\min \left[\frac{D}{H} \cdot K \cdot S_{\text {arc }} \cdot \frac{Y}{E}\right],
$$

where

$$
\begin{array}{lll}
S_{\max } & - & \begin{array}{l}
\text { maximum allowable value of the vertical settlement component, } \\
\text { inches }
\end{array} \\
S_{\text {arc }} & - & \text { effective length of the uneven settlement arc, feet; } \\
D & - & \text { tank diameter, feet } \\
Y & - & \text { yield strength of tank metal, } \mathrm{lbf} / \mathrm{in}^{2} ; \\
E & - & \text { Young's modulus, feet; } \\
H & - & \text { tank height, feet; } \\
K & - & \text { dimensionless parameter depending on the type and diameter of the } \\
& & \text { tank, selected according to the data in Table } 1 \text { and Table } 2 .
\end{array}
$$

\begin{tabular}{|c|c|c|c|c|c|c|c|}
\hline $\begin{array}{l}\text { VST diameter, } \\
\text { feet }\end{array}$ & $\begin{array}{l}P \\
\text { ñ } \\
\text { VI } \\
0\end{array}$ & $\begin{array}{c}\bar{\infty} \\
\vdots \\
\vdots \\
\ddot{0}\end{array}$ & 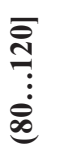 & $\begin{array}{c}\bar{\Xi} \\
\stackrel{\infty}{\vdots} \\
\vdots \\
\stackrel{\Xi}{\Xi}\end{array}$ & 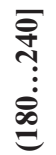 & 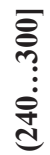 & $\begin{array}{l}\text { V } \\
\text { V } \\
\text { \&्ల }\end{array}$ \\
\hline $\begin{array}{l}\text { K, VST with a } \\
\text { fixed roof }\end{array}$ & 10.5 & 5.8 & 3.9 & 2.3 & - & - & - \\
\hline
\end{tabular}

Table 1. Selection of the Coefficient K Depending on VST Diameter, according to API-653 [12].

Table 2. Parameters of VST-20000 for Calculating Allowable Settlement, according to (1).

\begin{tabular}{|c|c|c|c|c|c|c|}
\hline Parameter & $\mathbf{S}_{\text {are }}, \mathbf{m}$ & $\mathbf{D}, \mathbf{m}$ & $\begin{array}{c}\text { Y(09G2S), } \\
\mathbf{M P a}\end{array}$ & $\mathbf{E , ~ M P a}$ & $\mathbf{H}, \mathbf{m}$ & $\begin{array}{c}\text { Coefficient } \\
\mathbf{K}\end{array}$ \\
\hline Value & 6.72 & 45.6 & 325 & 210,000 & 14 & 2.3 \\
\hline
\end{tabular}

In order to verify the calculated parameters of VST-20000, length of the settlement arc $\mathrm{S}_{\mathrm{arc}}$ was assumed to be from 6 to 72 meters. Other parameters of the tank are presented in Table 2. Using the formula (1), we obtained maximum settlement values for points of the outer bottom contour depending on the size of VST-20000 uneven settlement zone. In Figure 1, these relationships are presented graphically. 


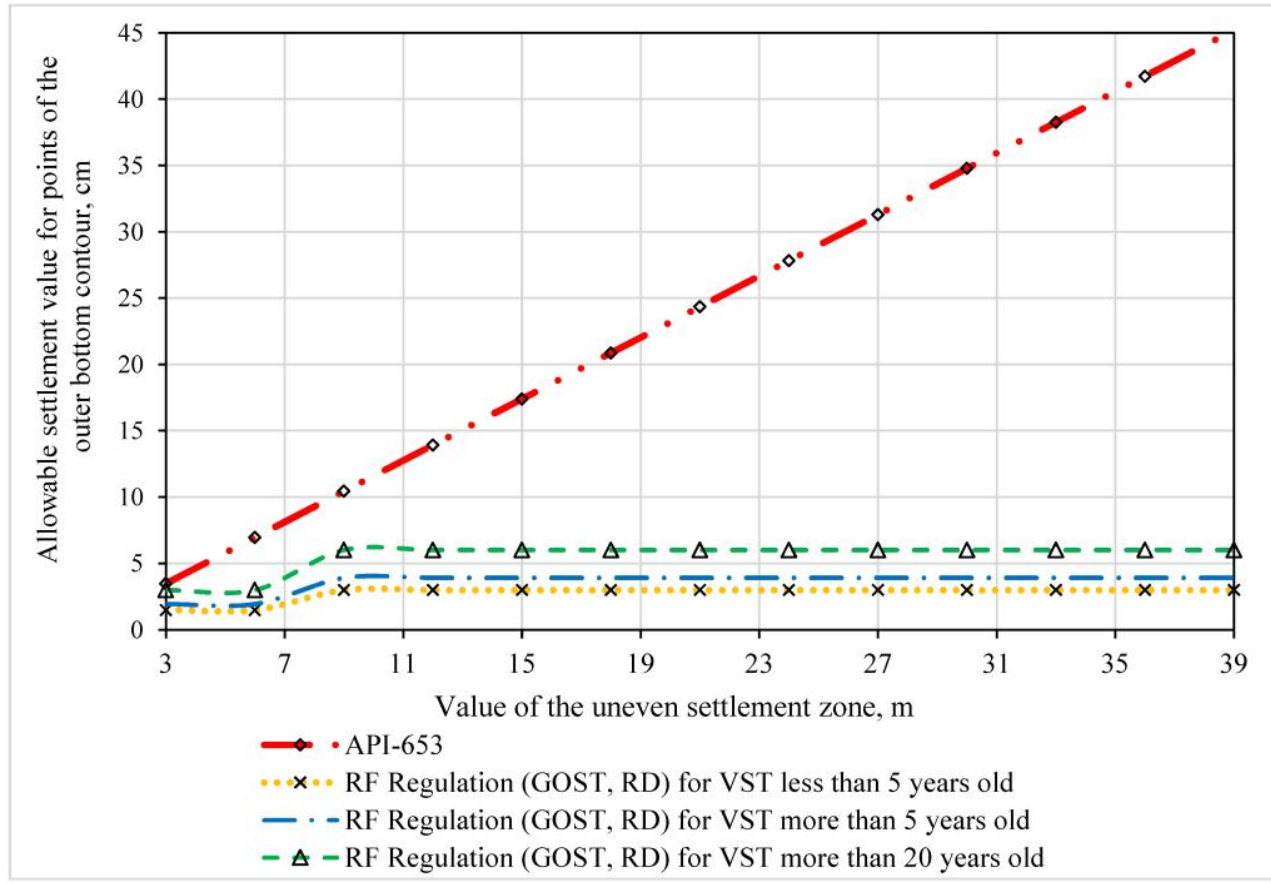

Fig. 1. Requirements of Russian and U.S. technical regulations that determine maximum settlement values for points of the outer bottom contour depending on the size of the VST uneven settlement zone.

The graph also shows maximum settlement values according to the industry standard RD-23.020.00-KTN-283-09 of OAO AK Transneft [13]. It can be seen that the maximum tolerances for uneven settlement in API-653 [12] are much broader than in the Russian standard, which is especially evident when the uneven settlement zone exceeds $10 \mathrm{~m}$. This difference is explained by greater stiffness of tanks constructed according to API.

To calculate the stress-strain state of the VST-20000 tank at the maximum values determined in [14], the authors suggest using the finite element model for a storage tank developed in [15]. Based on the model developed with the ANSYS Workbench 16.1 software, it is possible to determine equivalent stresses and strains of VST metal structures when specifying settlement parameters - length of the uneven settlement zone and vertical component [16-18]. The calculation algorithm, boundary and contact conditions, as well as loading parameters for the model are described in detail in [15].

\section{Results and Discussion}

Figures 2-4 show the results of numerical simulation of the VST-20000 settlement process for uneven settlement zones with a length of 12 and $72 \mathrm{~m}$ and vertical components with a size of $10,30,100 \mathrm{~mm}$. 


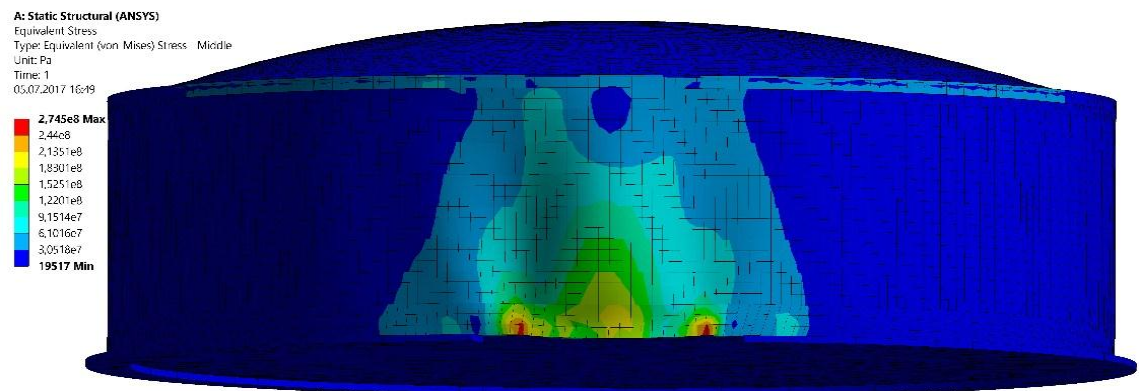

Fig. 2. Effective stresses at 10-mm settlement with 12-meter-long uneven settlement zone.

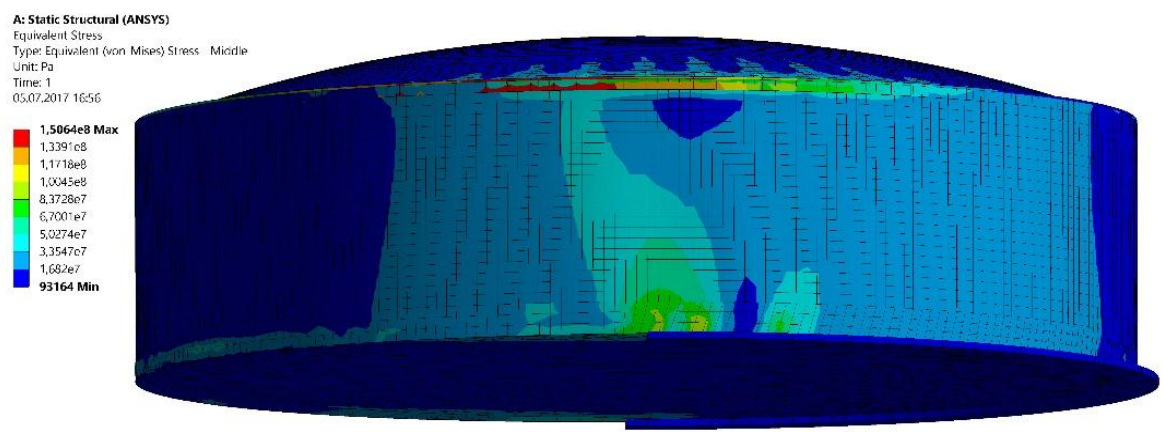

Fig. 3. Effective stresses at 30-mm settlement with 72-meter-long uneven settlement zone.

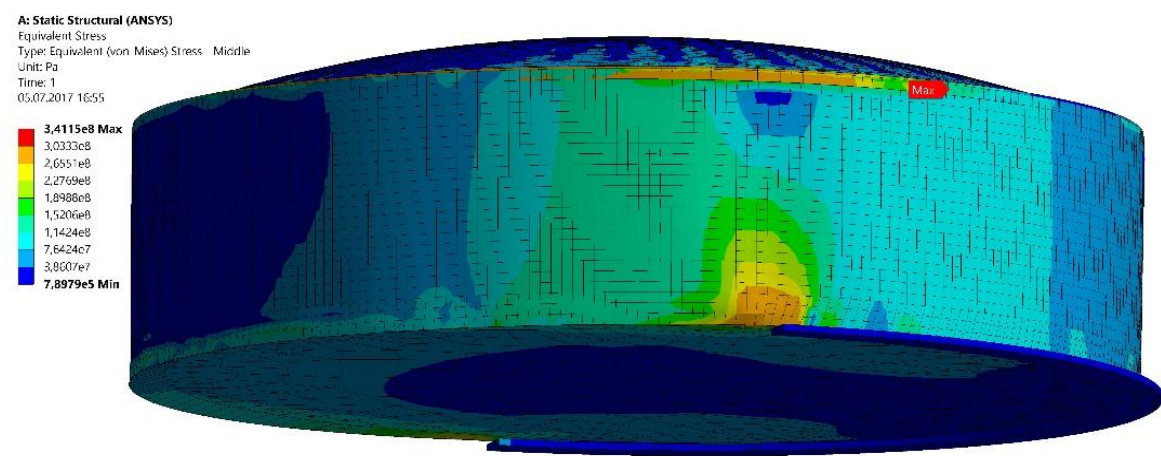

Fig. 4. Effective stresses at 100-mm settlement with 72-meter-long uneven settlement zone.

As a result of post-processing treatment, we obtained relationships of maximum equivalent stresses in VST metal structures to the vertical settlement component for zones with a length of 6 to $72 \mathrm{~m}$. The graph below (Fig. 5) indicates three limiting zones. In zone I, stresses in metal structures do not exceed the allowable values specified in Russian technical regulations $(188 \mathrm{MPa})$. In the second zone, stresses exceed the allowable values. In the third zone, inadmissible plastic strains occur. 


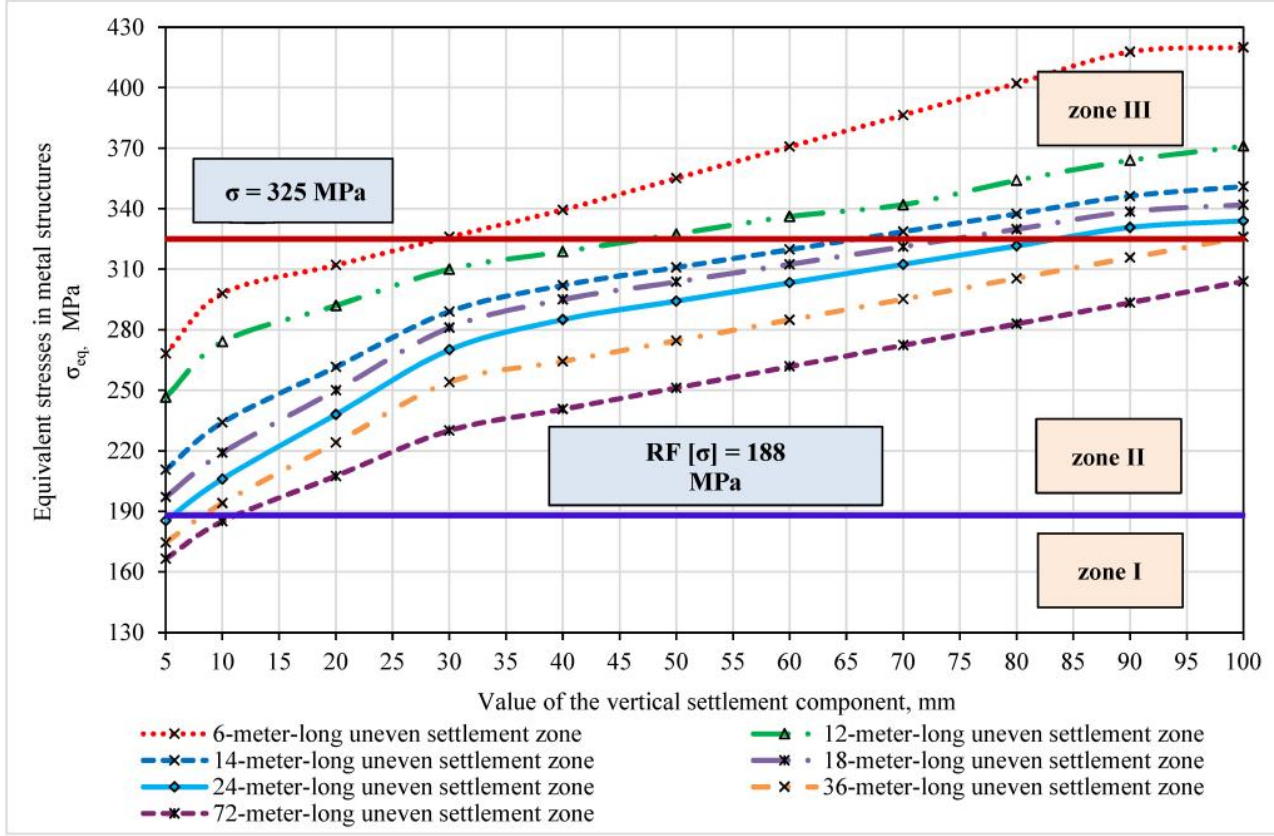

Fig. 5. Relationships of maximum equivalent stresses in VST metal structures to the vertical settlement component for uneven settlement zones with a length of 6 to $72 \mathrm{~m}$.

The obtained relationships indicate that the limit state in the VST-20000 design is reached at a $100-\mathrm{mm}$ vertical settlement and uneven settlement zone with a length up to $72 \mathrm{~m}$. According to [12], the allowable settlement for tanks based on the API standard is distortion with a 500-mm vertical component and uneven settlement zone with a length of $45 \mathrm{~m}$. This clearly suggests that the U.S. standards are not directly applicable to assessing uneven settlement of Russian vertical steel tanks. In order to use approaches of the standard [12] and to harmonize the Russian standards as related to the assessment of uneven foundation settlements, additional calculations are required.

\section{Conclusion}

The comparison of the allowable settlement levels according to [12] with those specified in Russian standards [13] shows that the settlement tolerances established in Russian documents are much more stringent than the U.S. ones (Fig. 1). Finite-element modeling of settlement allowed us to determine stresses and strains caused by non-axisymmetric deformation of the structure. The results based on the numerical model reflect the real deformation behavior of VST metal structures, which confirms the scientific and practical value of this study. Based on the calculations performed, it can be concluded that the criteria presented in [12] cannot be used to determine the allowable uneven settlement of VST tanks constructed according to the Russian standards. For this purpose, it is necessary to conduct additional studies of the stress-strain state for determining the coefficients in formula (1) that would reflect stiffness characteristics of the VST-20000 tank. Then the proposed approach [12] could be extended to the Russian tank construction industry. 
This paper was prepared as the basic part of the State Assignment for project No. 7.7858.2017/BCh: Scientific Justification of the Technique for Determining the Stress-Strain State of Large-Size Oil Storage Tanks in Case of Uneven Bottom and Foundation Settlements.

\section{References}

1. G.G. Vasilyev, A.A. Salnikov, Neftyanoe khozyaystvo [Oil Industry] 2, 106-108 (2015) (in Russian)

2. I.M. Rozenshtein, Avarii i nadezhnost' stal'nyh rezervuarov [Accidents and reliability of steel tanks] (Nedra, Moscow, 1995) (in Russian)

3. A. Akhavan-Zanjani, A. Fakher, S.R. Maddah-Sadatieh, A numerical study on the effect of uneven settlements of oil storage tank, 2nd International Conference on New Developments in Soil Mechanics and Geotechnical Engineering (Nicosia, North Cyprus, May 28-30, 2009)

4. J.S. Clarke, Recent tank bottom and foundation problems (Division of Refuting, 1971)

5. E.E. De Beer, Annales de L'Institut Belge du Petrole 6, 25-40, (1969)

6. D.A. Greenwood, Proceedings of the Conference on Settlement of Structures, 35-97 (British Geotechnical Society, Cambridge, UK, 1974)

7. A.S. Gorelov, Neodnorodnye gruntovye osnovanija i ih vlijanie na rabotu vertikal'nyh stal'nyh rezervuarov [Inhomogeneous ground base and their influence on the operation of vertical steel tanks] (Nedra, SPb, 2009) (in Russian)

8. I.V. Slepnev, Naprjazhenno-deformirovannoe uprugoplasticheskoe sostojanie stal'nyh vertikal'nyh cilindricheskih rezervuarov pri neravnomernyh osadkah osnovanij [Stress-strain elastic-plastic state of steel vertical cylindrical tanks with irregular immersion of bases] (MISI, Moscow, 2014) (in Russian)

9. EN 14015-2004. Specification for the design and manufacture of site built, vertical, cylindrical, flat-bottomed, above ground, welded, steel tanks for the storage of liquids at ambient temperature and above (2004)

10. BS 2654. Manufacture of vertical steel welded non-refrigerated storage tanks with butt-welded shells for the petroleum industry (1989)

11. A. Gruchenkova, A. Tarasenko, P. Chepur, D. Tarasenko, AIP Conference Proceedings 1800, 040019 (2017)

12. API 653. Tank Inspection, Repair, Alteration, and Reconstruction, Fourth Edition (USA, Washington, 2009)

13. RD-23.020.00-KTN-283-09. Rules of repair and reconstruction of oil storage tanks 1000-50000 cubic meters in capacity (2009)

14. A.A. Tarasenko, P.A. Konovalov, F.F. Zekhniev, P.V. Chepur, D.A. Tarasenko, Soil Mechanics and Foundation Engineering 53(6), 405-411 (2017)

15. A. Tarasenko, P. Chepur, A. Gruchenkova, MATEC Web of Conferences 73, 01025 (2016)

16. G.E. Korobkov, R.M. Zaripov, I.A. Shammazov, Chislennoe modelirovanie naprjazhenno-deformirovannogo sostojanija $i$ ustojchivosti truboprovodov $i$ rezervuarov $v$ oslozhnennyh uslovijah jekspluatacii [Numerical modelling of the stress-strain state and stability of pipelines and tanks in complicated operating conditions] (Nedra, Saint Petersburg, 2009)

17. V.A. Bruyaka, V.G. Fokin, E.A. Soldusova, N.A. Glazunova, I.E. Adeynov, Inzhenernyj analiz $v$ ANSYS Workbench [Engineering analysis in ANSYS Workbench] (SamSTU, Samara, 2010) (in Russian)

18. A.V. Beloborodov, Ocenka kachestva postroenija konechno-jelementnoj modeli $v$ ANSYS [Evaluation of the finite element model construction quality in ANSYS] (Ural State Technical University, Ekaterinburg, 2005) 